\title{
Eye emergencies in children and adults: epidemiological analysis of a Latin American center
}

\section{Urgencias oculares en niños y adultos: análisis epidemiológico de un centro latinoamericano}

\author{
Alexander M. Martínez-Blanco* \\ Department of Ophthalmology, VISOC group, Universidad del Valle; Department of Ophthalmology, Hospital Universitario del Valle, Clínica Imbanaco \\ Grupo QuirónSalud. Cali, Colombia
}

\begin{abstract}
Objective: To analyze eye diagnoses in children and adults admitted to an emergency room of a Latin American center. Method: Retrospective analysis of patients admitted to the emergency room of Hospital Universitario del Valle Evaristo García E.S.E in Cali, Colombia from January 2015 through December 2020 due to eye conditions and disorders. Diagnoses were analyzed according to the International Classification of Diseases, tenth revision. Results: A total of 7938 urgent visits due to eye diseases or disorders were analyzed. Of these, $62.7 \%(n=4974)$ were blunt eye traumas, and among the non-traumatic causes, $13.8 \%(n=1099)$ were anterior segment injuries, and $9.5 \%(n=757)$ were posterior segment injuries. The leading diagnoses were cornea/conjunctiva foreign body $(n=2697,34.0 \%)$, followed by eye contusion $(n=952,12.0 \%)$, and other disorders of the cornea/conjunctiva $(n=755,9.5 \%)$. Among the foreign body visits, $5.1 \%(n=137)$ were recurrent events. In patients under 18 years of age, more cases of contusions, eye burns, and tumors were reported compared to other age groups $(P<.05)$. In patients over 65 years of age, more urgent visits due to conjunctival hemorrhage, secondary glaucoma, macular degeneration, and endophthalmitis were reported $(P<.05)$. Conclusions: In children, adolescents, and adults, eye trauma was the most common cause for consultation in the study period, especially among men. The corneal foreign body was the most common mechanism. Visits due to anterior and posterior segment injuries were common in patients over 65 years.
\end{abstract}

Keywords: Eye emergencies. Eye trauma. Epidemiology. Cornea foreign body. Eye burns. Glaucoma.

\section{Resumen}

Objetivo: Analizar los principales diagnósticos oculares en niños y adultos que consultaron al departamento de urgencias en un centro de alta complejidad latinoamericano. Método: Análisis retrospectivo de pacientes que consultaron al departamento de urgencias por causas oculares en el Hospital Universitario del Valle Evaristo García E.S.E en Cali, Colombia, entre enero de 2015 y diciembre de 2020. Se analizaron la información demográfica y los diagnósticos de consulta de acuerdo con la Clasificación Internacional de Enfermedades 10. ${ }^{a}$ revisión. Resultados: Se atendieron 7938 visitas urgentes por condiciones oculares, de las cuales el $62.7 \%(n=4974)$ correspondieron a lesiones oculares traumáticas, $y$ entre las causas no traumáticas el $13.8 \%$ ( $n=1099)$ fueron por patologías del segmento anterior y el $9.5 \%$ ( $n=757)$ por patologías del seg-

Correspondence:

*Alexander M. Martínez-Blanco

Calle 5 36-08 Date of reception: 21-06-2021

Cali760042, Colombia

E-mail: alexander.m.martinez@correounivalle.edu.co
Disponible en internet: 31-01-2022 Rev Mex Oftalmol (Eng). 2022;96(1):9-13 www.rmo.com.mx 2604-1731/@ 2021 Sociedad Mexicana de Oftalmología. Published by Permanyer. This is an open access article under the CC BY-NC-ND license (http://creativecommons.org/licenses/by-nc-nd/4.0/). 
mento posterior. Los tres primeros diagnósticos de consulta fueron cuerpo extraño en la córnea o la conjuntiva ( $n=2697$, $34.0 \%)$, trauma contuso ( $n=952,12.0 \%$ y y otras alteraciones de la córnea o de la conjuntiva $(n=755,9.5 \%)$. El $5.1 \%(n=137)$ de las consultas por cuerpo extraño correspondieron a eventos recurrentes. En pacientes menores de 18 años se encontró una mayor proporción de casos con traumas contusos, quemaduras y tumores oculares en comparación con otros grupos etarios $(p<0.05)$. En los mayores de 65 años se encontró un mayor porcentaje de visitas urgentes por hemorragia conjuntival, glaucoma secundario, degeneración macular y endoftalmitis $(p<0.05)$. Conclusiones: En niños, adolescentes y adultos, el trauma ocular fue el motivo de consulta más frecuente en el periodo de estudio, especialmente en los hombres. El cuerpo extraño en la córnea fue la causa más común. Las consultas por patologías del segmento anterior y posterior fueron más frecuentes en los mayores de 65 años.

Palabras clave: Urgencias oculares. Trauma ocular. Epidemiología. Cuerpo extraño en córnea. Quemaduras oculares. Glaucoma.

\section{Introduction}

Visual disability plays an important role in people's quality of life, with direct and indirect costs that end up impacting society'. Although most ophthalmological conditions are treated in the outpatient setting, there are eye symptoms and conditions that prompt the patients' visits to the emergency room, which amounts to $1 \%$ to $7.6 \%$ of the overall number of visits reported ${ }^{2-4}$. The presence of red eye, sudden loss of visual acuity, and blunt eye trauma are the emergency ophthalmological causes more commonly reported 5 . However, they can vary depending on the social context and the healthcare system in each region.

The epidemiology of emergency ophthalmological visits has been properly described mainly in developed countries $^{6-8}$, which has triggered better planning strategies, use of the resources available, better preparedness for the emergency services to provide timely care, the best treatment available, and eventually a positive impact on the patient's visual prognosis ${ }^{9}$.

In Latin America, especially Colombia, access to specialized outpatient healthcare is limited, and waiting times can be long, which makes a portion of cases with conditions that can be treated as an outpatient, end up seeking healthcare at the emergency setting. In addition, in other contexts, it has been reported that $40 \%$ to $70 \%$ of all patient visits to the emergency room are due to non-emergency eye diseases and disorders ${ }^{6,10-12}$. This causes the collapse of the response capacity of the emergency room teams. Consequently, deep knowledge of the epidemiology of eye disorders that may require emergency care can help decision-makers in the process of creating policies to improve patient care and optimize the use of resources in Latin American healthcare systems. Therefore, the objective of this study is to analyze the main ocular diagnoses in children and adults admitted to an emergency room of a highly complex Latin American center.

\section{Method}

A retrospective analysis of all the patients admitted consecutively with eye disorders was conducted at the emergency room of Hospital Universitario del Valle Evaristo García E.S.E in Cali, Colombia from January 12015 through December 31, 2020. This investigation was conducted in a public teaching hospital that is a reference center for medical care in the Southwest region of the country providing healthcare to a population with low and medium socioeconomic levels. The Universidad del Valle Ethics Committee approved this study (code 172-020) that was conducted in full compliance with all the principles established in the Declaration of Helsinki.

The cases were identified using the electronic medical records by filtering the diagnoses at discharge related to eye disorders using the International Classification of Diseases, $10^{\text {th }}$ review (CIE-10). Diagnoses were grouped into six categories: trauma, anterior segment injuries, posterior segment injuries, glaucoma, infections, and others.

The descriptive analysis was conducted using the Stata statistical software, version 16.0 (StataCorp, College Station, TX, United States). Qualitative variables were expressed as absolute frequencies and percentages, and the quantitative ones as means and standard deviations. The diagnosis comparison based on sex and age group was conducted using the Pearson chi-square test and Fisher's exact test. $P$ values $<.05$ were considered statistically significant.

\section{Results}

During the study period, a total of 7938 patients were admitted to the emergency room due to eye disorders, with an average of 1323 consultations per year. Of all the visits to the emergency room, eye 


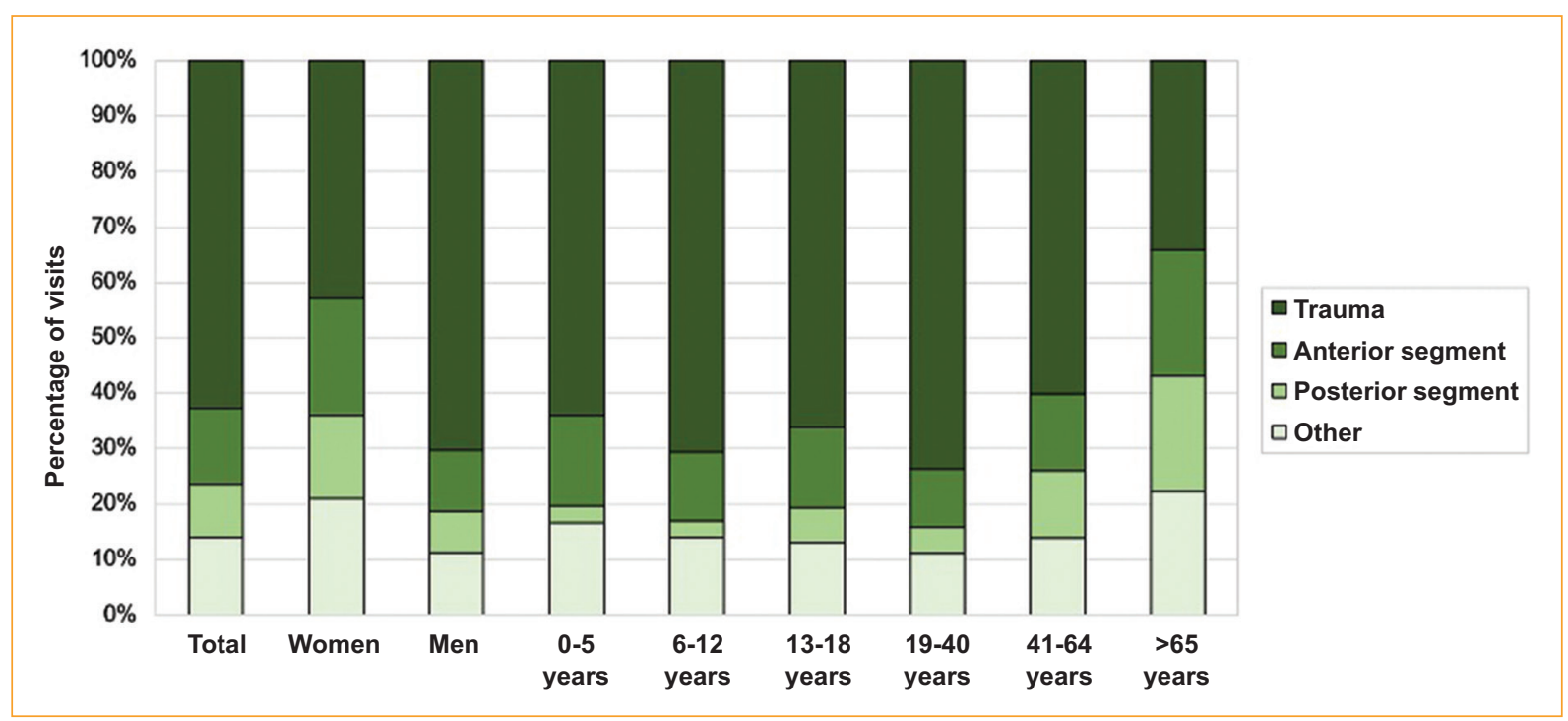

Figure 1. Distribution of ophthalmological diagnoses based on sex and age.

disorders represented $2.6 \%$ (7938/303 002). The mean consultation age was $41.4 \pm 19.8$ years and $71.9 \%(n=5705)$ were men. The most common reason for the visit was blunt eye traumas $(n=4974$, $62.7 \%)$ followed by anterior segment injuries $(n=1099,13.8 \%)$, posterior segment injuries $(n=757$, $9.5 \%)$, and infections $(n=332,4.1 \%)$. The least common causes were glaucoma $(n=70,0.9 \%)$, and eye tumors $(n=46,0.6 \%)$. A total of $8.3 \%(660)$ of the visits were due to some other type of eye damage different from the ones described above. Figure 1 shows that blunt eye trauma was the most common condition for the visits on both men and women, as well as in all age ranges. However, the rate of blunt eye trauma in men was 1.6 times higher compared to women (male/female: $70.3 / 43.0 \%$ ) with a statistically significant difference $(P<.001)$. Blunt eye trauma was more common at ages between 6 and 12 years old (70.6\%), and between 19 and 40 years old (73.7\%), and less frequent in people over 65 (34.1\%). Anterior and posterior segment injuries were more common in women and adults over $65(P<.001)$.

The leading five specific diagnoses that made these patients visit the emergency room were corneal foreign body $(n=2499,31.5 \%)$, eye contusion ( $n=952,12.0 \%)$, other corneal or conjunctival disorders $(n=755,9.5 \%)$, eyelid trauma ( $n=593,7.5 \%$ ), and burns ( $n=523$, $6.6 \%$ ). In patients under 18 years, many more cases of contusion, eye burn, and tumors were reported $(P<.05)$ compared to other age groups. In people over 65 years old many more cases of visits to the emergency room due to conjunctival hemorrhage, secondary glaucoma, macular degeneration, and endophthalmitis were reported $(P<.05)$. Retinal detachments were seen mainly in patients over 40 years old (Table 1).

The presence of a foreign object in the eye was seen more frequently in patients between 19 and 64 years of age $(P<.05)$, with a total of $2697(34.0 \%)$ visits to the emergency room in 2560 individuals; of these, $88.2 \%$ (2258) were male visits with a mean age of $40.6 \pm 15.8$ years. A total of $5.1 \%(n=137)$ of the visits due to foreign object situations in the eye had to do with recurring events.

\section{Discussion}

The main finding of this study revealed that the presence of a foreign body in the eye is the most common reason for visiting the emergency room in a high-complexity hospital in Cali, Colombia. It represents 1 for every three ophthalmological visits. Same as it happens in other countries such as Thailand ${ }^{13}$, Taiwan ${ }^{14}$, and Pakistan ${ }^{2}$, blunt eye trauma is the first reason for visiting the emergency room. However, this is not the case in countries like The United States of America ${ }^{6}$, Spain $^{5,12}$, and Brazil ${ }^{15}$, where infectious conditions (e.g., conjunctivitis) are the leading cause for consultation.

Blunt eye trauma is considered an important cause of visual disability and preventable blindness worldwide with a greater number of cases of blindness reported in developing countries (75/100 000 compared to $9 / 100000$ 
Table 1. Specific ophthalmological diagnoses by age

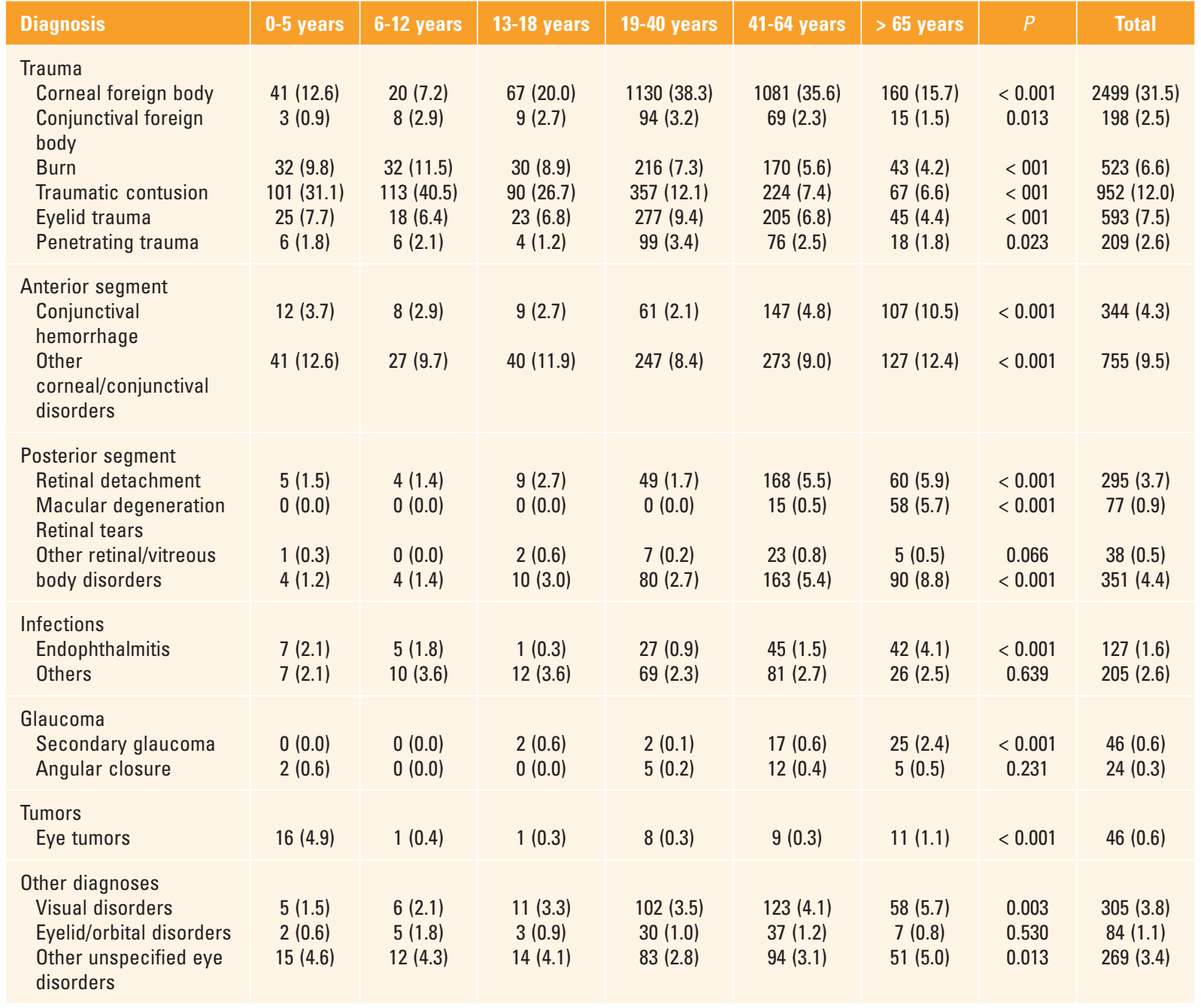

in developed countries ${ }^{16}$. Similar to what has been reported by other authors ${ }^{5,6,17}$, many more cases with blunt eye trauma were found in men during their second and third decades of life. This has to do with the fact that blunt eye trauma and damage to surrounding structures are usually associated with work-related activities.

A foreign body in the cornea or the conjunctiva was the main mechanism of eye injury ${ }^{16}$. In this study, recurring visits for this reason were found, which is indicative that there is a lack of programs aimed at educating the patient in the use of biosafety occupational measures to prevent recurrences. The presence of a foreign body can have an impact on the patients' visual quality with a broad spectrum of damage, including refractive problems, keratitis, and permanent visual compromise, which vary depending on the size of the injury and management of such injury ${ }^{18}$.
On the other hand, in children and teenagers, the main reason for visiting the emergency room was traumatic contusion associated with recreational activities ${ }^{19}$. This finding is different from the one reported in Spain where conjunctivitis was the most common cause for visiting the emergency room in this age group $\left(29 \%\right.$ of all visits) ${ }^{20}$. across the world, in both children and teenagers, most visits to the emergency room are due to red eye that can be initially attributed to infectious diseases ${ }^{6}$. In our context, these types of diseases are treated outpatiently, which would explain the diagnosis distribution reported in this investigation.

Another significant finding is the large number of eye burns. In another study also conducted in Cali, Colombia, it was found that most eye burns were due to chemicals $(62.7 \%)$, thermal agents $(28.7 \%)$, and UV radiation $(6.8 \%)$. Also, they occurred while doing 
domestic chores or at the workplace, being men the group most affected (a 2:1 ratio compared to women) ${ }^{21}$.

Our study has certain limitations. First, due to its retrospective nature, we did not manage to make a more precise characterization of the cases, for example, in aspects regarding the symptoms reported, the patient's occupation or the injury mechanisms, among others. Second, the data presented come from a single Latin American center located in Cali, Colombia; therefore, the extrapolation of the results reported should take place in the light of each context. And third, during case review, it was found that a substantial number of cases were categorized as «others» in their discharge diagnosis. Therefore, it is essential to encourage all ophthalmologists to describe the cases using CIE-10 with higher precision, which can be helpful in future studies.

\section{Conclusions}

In children, teenagers, and adults, blunt eye trauma was the most common reason for consultation in the study period, especially among men. Corneal foreign bodies were the most common injury mechanism. Consultation for anterior segment and posterior segment injuries was more common in those over 65 years.

\section{Funding}

The authors declare that for this research no external sources of financing were used to conduct this study.

\section{Conflicts of interest}

The authors did not declare any conflict of interest.

\section{Ethical disclosures}

Protection of human subjects and animals in research. The authors declare that the procedures followed were in accordance with the regulations of the relevant clinical research ethics committee and with those of the Code of Ethics of the World Medical Association (Declaration of Helsinki).

Patients' data protection. The authors declare that they have followed the protocols of their work center on the publication of patient data.

Right to privacy and informed consent. The authors have obtained the approval from the ethics committees (code 172-020) and observed the requirements in the handling of information.

\section{References}

1. McKean-Cowdin R, Varma R, Wu J, Hays RD, Azen SP, Group LALES. Severity of visual field loss and health-related quality of life. Am J Ophthalmol. 2007;143:1013-23.

2. Baig R, Ahmad K, Zafar S, Khan NU, Ashfaq A. Frequency of ocular emergencies in a tertiary care setting in Karachi, Pakistan - It is time to reduce unnecessary visits. J Pak Med Assoc. 2018;68:1493-5.

3. Girard B, Bourcier F, Agdabede I, Laroche L. Activity and epidemiology in an ophthalmological emergency center. J Fr Ophtalmol. 2002;25:701-11.

4. Zafar S, Sebestyen K, Qureshi Z, Schein O, Johnson P, Srikumaran D, et al. National trends in imaging rates for eye-related emergency department visits in the United States. Am J Ophthalmol. 2020;211:114-22.

5. Galindo-Ferreiro A, Sánchez-Tocino H, Varela-Conde Y, Díez-Montero C, Belani-Raju M, García-Sanz R, et al. Ocular emergencies presenting to an emergency department in Central Spain from 2013 to 2018. Eur J Ophthalmol. 2021;31:748-53.

6. Channa R, Zafar SN, Canner JK, Haring RS, Schneider EB, Friedman DS. Epidemiology of eye-related emergency department visits. JAMA Ophthalmol. 2016;134:312-9.

7. Agrinier N, Conart J-B, Baudot A, Ameloot F, Angioi-Duprez K. Caractéristiques des patients examinés en urgence par un ophtalmologiste dans un CHU: résultats d'un étude transversale analytique identifiant des facteurs associés au caractère de véritable urgence. J Fr Ophtalmol. 2018;41:546-53.

8. McCarty CA, Fu CL, Taylor HR. Epidemiology of ocular trauma in Australia. Ophthalmology. 1999;106:1847-52.

9. Cheung CA, Rogers-Martel M, Golas L, Chepurny A, Martel JB, Martel JR. Hospital-based ocular emergencies: epidemiology, treatment, and visual outcomes. Am J Emerg Med. 2014;32:221-4.

10. Carvalho R de $\mathrm{S}$, José NK. Ophthalmology emergency room at the University of São Paulo General Hospital: a tertiary hospital providing primary and secondary level care. Clinics (Sao Paulo). 2007;62:301-8.

11. Hau S, Ioannidis A, Masaoutis $P$, Verma S. Patterns of ophthalmological complaints presenting to a dedicated ophthalmic accident \& emergency department: inappropriate use and patients' perspective. Emerg Med J. 2008:25:740-4.

12. Domínguez-Serrano FB, Molina-Solana $P$, Infante-Cossío M, Sala-Turrens J, Seva-Silva N, Rodríguez-de-la-Rúa-Franch E. Ophthalmological emergencies. An epidemiological study: are resources been used properly? Arch Soc Esp Oftalmol. 2019;94:211-7.

13. Imsuwan I, Amnuaypattanapon $\mathrm{K}$, Vongkittirux S, Imsuwan $\mathrm{Y}$. The study of incidence and characteristics of patients with eye-related chief complaints at the emergency department of Thammasat University Hospital. Emerg Med Int. 2020;2020:4280543.

14. Hsu MH, Hsu CA, Hsiao SH, Chu D, Yen JC. Utilization of emergency ophthalmology services in Taiwan: a nationwide population study. Sci Rep. 2020;10:1-6.

15. Sen E, Celik S, Inanc M, Elgin U, Ozyurt B, Yılmazbas P. Seasonal distribution of ocular conditions treated at the emergency room: a 1-year prospective study. Arq Bras Oftalmol. 2018;81:116-9.

16. Feng K. Epidemiology of ocular trauma. En: Yan H, editor. Anatomy and examination in ocular trauma. Singapore: Springer; 2019. p. 105-22.

17. Fea A, Bosone A, Rolle T, Grignolo FM. Eye injuries in an Italian urban population: report of 10,620 cases admitted to an eye emergency department in Torino. Graefes Arch Clin Exp Ophthalmol. 2008;246:175-9.

18. Liu Y, Wang S, Li Y, Gong Q, Su G, Zhao J. Intraocular foreign bodies: clinical characteristics and prognostic factors influencing visual outcome and globe survival in 373 eyes. J Ophthalmol. 2019;2019:5208092.

19. Oiticica-Barbosa MM, Kasahara N. Eye trauma in children and adolescents: perspectives from a developing country and validation of the ocular trauma score. J Trop Pediatr. 2015;61:238-43.

20. Henriquez-Recine, Noval S, Zafra B, De Manuel S, Contreras I. Ocular emergencies in children: demographics, origin, symptoms, and most frequent diagnoses. J Ophthalmol. 2020;2020:6820454.

21. Ocampo HH, Contreras JC, Martínez A, Amaya CA, Bonilla-Escobar FJ. Quemaduras oculares en un centro de referencia oftalmológica de Santiago de Cali, Colombia. Colomb Med. 2008;39:210-8. 